\title{
THE OPENNESS OF THE ECONOMY AS A DYNAMIC PROCESS
}

\author{
Associate Professor PhD Ivan Iliev, University of Economics - Varna, Bulgaria, \\ ilievvarna@yahoo.co.uk \\ Associate Professor PhD Georgi Marinov, University of Economics - Varna, Bulgaria, \\ gmarinov@yahoo.com,gmarinov@ue-varna.bg \\ (participation of both authors should be considered as equal)
}

\begin{abstract}
The issue of the openness of the economy is becoming more important recently, especially given the development of global economy in last years and months. As openness is to be regarded as a dynamic process, flexible in both directions, problems with the visions for the openness arise with time, especially for transitional economies, given the fragility of their markets. In applying some econometric methods on external trade data we aim to shed some light on the dynamics of the openness of the economy of Bulgaria after 2000.
\end{abstract}

Keywords: open economy, Grubel-Lloyd index, transitional economy

JEL Codes: F14, F41, O11, O52, P23

\section{The openness of the economy}

The search for the notion of the "open economy" is in fact a search for the ways of interaction between national and global macroeconomic systems, real processes and their (positive and negative) effects on various levels - citizens, societies, world. It is usually stated, that as national economies, so the world as a whole as well are becoming more and more open, that there is an overall trend towards open trade. But there is also a certain resistance against the open economy.

Historically the social sense of economy, the microeconomic participants in the economy perceive the external competition in their territory as a necessity, continuously leading the whole system towards efficiency, but as a whole external competition does not in fact face a benevolent treatment. In the words of V.Hugo - there is a resistance against invasion of armies. Sediments in the thoughts are ancient, and not neglectable - the own economy is regarded as "protectable" for local operators, but this is a sort of limit for the economic development, because it expels the external pressure for efficiency and creates the environment for monopolies and low flexibility.

The approach of states in the external economic relations often develops in leaps, sometimes there are significant difficulties, and definitely there are also attempts to avoid liberalization because of political considerations.

But as a whole decisions cannot be easily met - from the one side, there is the need to defend national interests, from the other side - the need for positioning of the country economy in the global economy, creating development and prosperity.

Thus - openness is a process, and not a state, and it develops with time.

World economy becomes more efficacious in the case there is movement of production factors (capital, labour) - migrating from low-productivity countries to countries with higher productivity. A specialized globally production is more solid prerequisite for factor movement, than is international trade.

Anyway the unreserved belief in the growth promoting power of trade, cultivated on the principle of relative advantages, is yet too strong. It is very widely socially supported, and it peaks in times of economic growth and widening of productive and consuming powers, although protectionist ideas are also alive, especially in times of economic downturns. That is why among 
economists the belief that economic theory defends liberal market order is spread. International division of labour and the following specialization in international dimensions acts as a catalyst for the economic ties and maintenance of sustainable economic relations among countries. In the case there is closing of the economy and isolationism, the world divides in agrar and industrial one, countries build their own industrial face, there is a disrupt between the structure of national production and national consumption.

Openness is usually interpreted as the extent to which there is external trade. Openness or closeness are external economic positions of the country, the choice between isolation and cooperation is a strategic one, a choice of way of functioning of the economy.

In the words of V.Marinov (see Marinov 2006:8), "the external position of the country is formed to a high extent by the presence (or lack) of national strategy and policy with long-term horizon and widespread span." This position is bound to shared values, beliefs, historic heritage, mentality, presence or lack of the so called economic patriotism. Of extreme importance is the belief of the moving forces of progress, which could push forward people and society.

Maintaining the openness of the economy is a process, most often a non-linear one. It is not an act, but it suggests acting - administrative acts, decisions of individuals and governing institutions which allow free trade relations between countries. Openness can be hindered by extreme protectionism, selectively narrowed through limitating instruments of trade policy, monetary policy, legislative initiative etc. Though its factor base is relatively wide. It depends on technological, economic conditions, as well as on purely political decisions, following ideological and other considerations. Anyway the reality definitely proves, that international economic relations, appearing as trade, production, transport and communication liaisons etc. remain particularly sensitive to political factors and political facts. Evidence in this direction could be found as in the past, as well as in recent days. In example exactly the political change in Central and Eastern Europe allowed in a relatively short time Eastern and Western Europe mutually to open to each other - a proof is the growth of absolute and relative shares of their trade, flows of investments, labour.

It is frequently claimed, that during the period of totalitarian rule, the economies of Central and Eastern Europe are practically closed, as a direct consequence of the specifics of the socialist system, which is identified as absolutely sterile, claustrophobic. Anyway the extent of closeness differs in the group - countries with traditionally closer ties to Western Europe - Czech Republic, Hungary - are less affected than more Eastern ones. Political considerations play far more important role than economic (see Kornai 1996).

Openness is not a question of good will, nor of chance, it appears, develops and unfolds as a process in return of objectively preconditioned needs and goals of economic activity. As a part of processes in the economy it hardly depends on the system, it rejects isolationism, it ensures a horizon for the nation in the economic world. Externally it appears as orientation of economic activity towards enclosure in international networks, as a process of seeking and finding of possibilities for effective realization of national economic interests through operating in broader than the national spaces, following the international strategy, setting on different combinations of external markets and forms of activity abroad. The orientation is towards multitude of markets, to a diversification of market portfolio.

The fact that macroeconomic theory concentrates mainly on trade, monetary and fiscal policy, on their standard instruments does not mean, that in the process of opening of national economy there are not any other ties between economies than trade and financial ones. In the same time it takes in consideration that the interdependence between national economies affects the ability of governments to control their own economic activity, insofar as by openness it is a reality the national economy to enter in international flows of goods, services, finances etc.

Openness of the economy should be regarded as a characteristics of macroeconomic system, as a philosophy, denying the prevailing of isolationism, seeming that is has no alternative. 
Economic liberalism, which results from the necessity of gaining economic rationality and efficiency, integrates the country in the global economy. The shift from policy of limitations towards liberal economic strategy creates an environment of moving of economy from protected to open state, its grade of economic and political openness grows with the diminishing of limitations to free trade, free movement of factors etc., with the legislative initiative regarding overall liberalization of economic life.

Openness of national economy as a sustainable trend, as dominating inception does not exclude some selective protectionism, concerning certain sectors of economic life, leading to practically hybrid situations, in some of which openness prevails, whereas in others protectionism dominates. In both cases (openness and protectionism) important is the degree to which economy is open or protected. No matter what the choice, functioning of the system is of utmost importance. Higher degree of openness of national economy makes less autonomous the decisions of macroeconomic policy, which by definition are supposed to serve the national interests. Now it is considered that national decisions will remain, even in a reality of vanishing national borders and growing interdependence of economies. And if a change is to be searched, fine tuning in regulative practice with the aim of higher efficiency of macroeconomic policy should be focused on international matters in their notion processes. As L. Thurow states, with the forwarding of internationalization, national governments loose many of their traditional levers for economic control, so that national economic orientations are dictated by supranational geo-economics powers. Local regulative system should work in pace with the supranational, it should orientate economic actions towards international requirements and trends, it should take in account the dominating powers in the world. It is a long time ago when determining the economic relations forces have grown beyond purely additive to the national development into a decisive and preconditioning ones.

The majority of modern economies are small open economies, they cannot influence their external economic partners. In the words of K. Pilbeam (see Pilbeam 1995:371), allowing for the economy to be "small and open" is necessary, because it permits to neglect possible reactions of its external economic partners on its policy. Practice is somewhat different, though - actions of one country could lead to counter-actions by its trade partners, which could strengthen, or lessen, or tame the effects of the policy.

And even there are some objections against it in academic writings, governmental intervention and support in the national economy is regarded as needed, and even more - it can purposely affect the development of the whole economic system.

Socio-historic experience gives plenty of plausible proofs of the possibilities to open a nationally delimited economy in order to include it in the process of internationalizing of economic life. Usually applied are two models - of total (radical, overall) opening, ensuring full-fledged openness of national borders according to full liberalism, and a governed and selective opening of local economic process towards external processes. By the latter model openness is not gained instantly, but rather gradually. It is often argued, that formerly totally closed economies should not be opened gradually, because of the possible new deformations in volume, production, prices etc. Newest economic history of Bulgaria acts as somewhat example and proof of it.

Modernizing, efficiency, competitivity, fast growth of national wealth is better to be acquired by total opening, as economic agents are able to faster and more flexible adapt to changing external conditions.

We try to analyse the type of openness of the Bulgarian economy in the second part of our paper.

\section{Dynamics of the openness of Bulgarian economy after the year 2000}

It after the year 2000 around which the economy of Bulgaria is believed (see EC 2003) to have become a market economy, although formal acknowledge of it is made somewhat later. 
Privatization of major enterprises has been done, and as well as macroeconomic stabilization after the introduction of currency board in 1997.

During first years after the introduction of the currency board there are major shifts in Bulgarian economy - mainly restructuring - closing and privatization of big state-owned firms, growing of unemployment, adjusting of inflation towards the currency of fixing etc. That is why, because of the structural change, data before 2000 is practically of little use for our analysis.

To be able to make some plausible conclusions about type of openness, we use data for the period after 1999. We use quarterly data on external trade (export and import by main trade regions and end use), published by the Bulgarian National Bank, for the period 2000-2008, from 2000:1 to 2008:2, 34 observations.

We track down the evolution of one of the most often used indexes for integration of the economy - the Grubel-Lloyd index (see Grubel and Lloyd 1975). It measures the degree to which trade relations with the external world are based on intra-industry trade, rather than on interindustry trade.

We use as a base of our calculations

$\mathrm{GL}=1-|\mathrm{Xi}-\mathrm{Mi}| /(\mathrm{Xi}+\mathrm{Mi})$

where Xi are the country's exports for i-th industry and Mi are the country's imports.

If trade relations are exclusively intra-industry ones, values of the index are close to 1 , whereas if trade is according to the classical beliefs - inter-industry based - values are close to 0 . According to modern views, highest degree of openness can be achieved between similar in their structure and degree of development economies. And exactly in such cases intra-industry trade prevails. Thus - the more the intra-industry trade, the more open the economy in the modern view of openness, as trade is only one aspect of openness, and in a world with prevailing intangible assets capital flows are far more important than trade ones. And capital and labour flows are most effective and have their biggest magnitude among similar economies. We aim to explore the openness of Bulgarian economy towards its major partners - countries of EU, incl. "old" EUcountries (EU-15) and "new" ones, as well as Balkan countries.

Anyway there are problems if the comparison is made between industrial countries and transitional countries. If economic growth is too high, then values of the index could be biased. Internal disparities in the economy - i.e. differences between rural and urban areas could have similar effects. Therefore we do not rely on absolute values, but use a different approach - we analyse the evolution of the index in the time. We test the index for unit roots in order to discover whether trade is steady or it is flexible enough to cope with the hypothesis that openness is not "once and forever".

If we cannot reject the presence of unit roots in the indexes, then Bulgarian economy is to believed that it is in a steady state - changes are past, and further changes in the future are not to be expected. If we can reject unit roots, openness of Bulgarian economy is to be viewed as flexible, for what concerns i.e. the possible shift from liberalism to protectionism or vice versa - it is not to be excluded.

Anyway it should be noted, that in transitional countries functioning of institutions is not always full-fledged, and there is also major share of informal economy, so governmental actions cannot in all cases be believed to make the full effect they are supposed to have.

We include seasonal dummies, in order to avoid some discrepancies, given the seasonality of data. Calculations are made with Gretl 1.7.9 software. Table 2).

Results are presented for the tests with no constant (see Table 1) and with constant (see

Results show that unit roots cannot be rejected only for few cases, what rather supports a statement like that openness of Bulgarian economy is a "dynamic" one. 
Table no. 1.

Results from ADF-tests (p-values) on GL-indexes, no constant

\begin{tabular}{|c|c|c|c|}
\hline & $E U-15$ & EU-new & Balkans \\
\hline Consumer goods & $0.96(4)$ & $0.65(1)$ & $0.68(6)$ \\
\hline Raw materials & $0.75(3)$ & $0.95(3)$ & $0.96(5)$ \\
\hline Investments & $0.96(7)$ & $0.58(3)$ & $0.43(1)$ \\
\hline Mineral fuels, oils and electricity & $0.56(2)$ & $0.63(6)$ & $0.34(1)$ \\
\hline
\end{tabular}

Source: own calculations, in parenthesis is given the lag order

Table no. 2.

Results from ADF-tests (p-values) on GL-indexes, with constant

\begin{tabular}{|c|c|c|c|}
\hline & $E U-15$ & EU-new & Balkans \\
\hline Consumer goods & $0.99(1)$ & $0.33(0)$ & $0.00(5)$ \\
\hline Raw materials & $0.61(0)$ & $0.25(0)$ & $0.12(0)$ \\
\hline Investments & $0.09(0)$ & $0.07(0)$ & $0.71(1)$ \\
\hline Mineral fuels, oils and electricity & $0.0(0)$ & $0.11(5)$ & $0.06(0)$ \\
\hline
\end{tabular}

Source: own calculations, in parenthesis is given the lag order

In the few cases in which unit roots could be rejected by a test with a constant, these results appealingly support the view that there is a deterministic trend, i.e. the economy of Bulgaria is in process of changing its type of openness. Anyway given the low power of unit root tests results could be interpreted also as controversial. Further analyze - i.e. for co integration, seems to be a meaningful extension of analysis.

\section{Conclusion}

On basis of trade statistics data and exploring the evolution of Grubel-Lloyd indexes for several trading partner countries groups of Bulgaria we were able to find that the openness of the economy of Bulgaria is a dynamic one. Appearingly there are some possibilities for reversion or changing the pace of the openness. Such result should not be regarded as surprising, given the transitional nature of the economy and the relative small volume of the economy, towards all groups that were taken in consideration.

\section{References:}

1. Grubel, H. and P. Lloyd, Intra-Industry Trade: The Theory and Measurement of International Trade in Differentiated Products, Wiley, New York, 1975.

2. Kornai, J., The Socialist System. Political Economy, (in Bulgarian), Ed. Marin Drinov, Sofia, 1996.

3. Marinov, V., Openness and Growth of National Economy (in Bulgarian), in UNWE Yearbook, UNWE Press, Sofia, 2006.

4. Pilbeam, K., International Finance (in Bulgarian), FT Press, Sofia, 1995.

5. Thurow, L., The Future of Capitalism. How Today's Economic Powers Model Tomorrow's World, (in Bulgarian), Vesela Lutskanova Ed., Sofia, 2000.

6. EC, Monitoring Report on Bulgaria's Preparations For Membership, EC, Brussels, 2003. 